CZASOPISMO INŻYNIERII LĄDOWEJ, ŚRODOWISKA I ARCHITEKTURY JOURNAL OF CIVIL ENGINEERING, ENVIRONMENT AND ARCHITECTURE

JCEEA, t. XXXII, z. 62 (3/I/15), lipiec-wrzesień 2015, s. 293-302

Katarzyna NOWAK-DZIESZKO ${ }^{1}$

Małgorzata ROJEWSKA-WARCHAL ${ }^{2}$

\title{
ANALIZA WARUNKÓW MIKROKLIMATU W LOKALU MIESZKALNYM BUDYNKU WIELKOPEYTOWEGO W SYSTEMIE W70
}

\begin{abstract}
Szacuje się, że w budynkach systemowych mieszka obecnie co czwarty Polak. Oznacza to, że zagadnienia związane $\mathrm{z}$ użytkowaniem budynków wielkopłytowych mają bardzo istotne znaczenie dla naszego społeczeństwa. Głównym analizowanym zagadnieniem jest ograniczenie energochłonności oraz poprawa izolacyjności budynków prefabrykowanych, a podstawowym kryterium podczas modernizacji tychże budynków mieszkalnych jest poprawa ich charakterystyki energetycznej. W celu zmniejszenia ponoszonych kosztów na utrzymanie budynków podejmowane są inwestycje mające na celu przede wszystkim poprawę izolacyjności cieplnej przegród, nie uwzględniając natomiast aspektu komfortu cieplnego oraz problemów związanych z przegrzewaniem budynków tak istotnego z punktu widzenia mieszkańców. Na podstawie licznych analiz przeprowadzonych przez autorów stwierdzono, że warunki mikroklimatu w wielorodzinnych budynkach wielkopłytowych są niekorzystne dla mieszkańców.

$\mathrm{W}$ artykule przedstawione zostaną wyniki obliczeń symulacyjnych warunków mikroklimatu w pojedynczym lokalu mieszkalnym, budynku systemowego W70, zlokalizowanym na różnych piętrach wielorodzinnego budynku mieszkalnego. Większość lokali mieszkalnych w budynkach wielkopłytowych ma powierzchnię około $50-60 \mathrm{~m}^{2}$, na których wydzielone są zwykle trzy pokoje, kuchnia oraz łazienka co sprawia że powierzchnia poszczególnych pomieszczeń jest bardzo mała. Średnia liczba mieszkańców to trzy osoby. Powyższe fakty wpływają bardzo niekorzystnie na komfort cieplny pomieszczeń co potwierdziły przeprowadzone analizy. W artykule wykazano również, że zastosowanie różnych form zacienień wewnętrznych oraz zewnętrznych mogłoby znacznie poprawić warunki mikroklimatu poszczególnych pomieszczeń. Symulacje zostały wykonane w programie Design Builder.
\end{abstract}

Słowa kluczowe: budynek wielkopłytowy, system W70, wielka płyta, komfort cieplny

1 Autor do korespondencji/corresponding author: Katarzyna Nowak-Dzieszko, Politechnika Krakowska, ul. Warszawska 24, 31-155 Kraków, tel. 1262823 17, knowakdzieszko@o2.pl

2 Małgorzata Rojewska-Warchał, Politechnika Krakowska, ul. Warszawska 24, 31-155 Kraków, tel. 1262821 32, m_rojewska@wp.pl 


\section{Komfort cieplny pomieszczeń}

Komfort cieplny jest pojęciem subiektywnym i dość trudnym do analizowania. Definiowany jest jako stan, w którym człowiek czuje, że jego organizm znajduje się w stanie zrównoważonego bilansu cieplnego i oceniany jest najczęściej dopiero na etapie użytkowania budynków. Na warunki komfortu cieplnego pomieszczenia wpływa szereg czynników: aktywność fizyczna użytkowników, izolacyjność odzieży oraz parametry otoczenia: temperatura powietrza, średnia temperatura promieniowania, prędkość przepływu powietrza oraz wilgotność względna powietrza.

Na podstawie normy [1] ocenę komfortu cieplnego dokonuje się za pomocą dwóch wskaźników PMV (Predicted Mean Vote) - statystyczny wskaźnik odczuwania ciepła i PPD (Predicted Percentage of Dissatisfied) - przewidywany odsetek niezadowolonych, które opierają się na metodzie Fangera. Ocena komfortu cieplnego z uwagi na dużą liczbę parametrów go opisujących jest dość problematyczna. Zastosowanie programów symulacyjnych pozwala na szczegółową ocenę wpływu rozwiązań projektowych i modernizacyjnych na mikroklimat mieszkaniach.

\section{Opis analizowanego budynku}

Symulację wykonano dla lokali mieszkalnych, istniejącego 11 kondygnacyjnego wielorodzinnego budynku mieszkalnego wykonanego w systemie W70, zlokalizowanego w Krakowie w dzielnicy Krowodrza (Rys. 1). Obliczenia przeprowadzono w programie Design Builder v.3., który pozwala na analizę termiczną obudowy budynku oraz mikroklimatu poszczególnych pomieszczeń budynku.

Analizowany budynek został wzniesiony w 1974 r. w technologii wielkopłytowej w systemie W70 (Rys. 1). Wymiary budynku w rzucie to $21,5 \mathrm{~m} \mathrm{x}$ $13,2 \mathrm{~m}$, wysokość kondygnacji $2,5 \mathrm{~m}$, powierzchnia użytkowa $-2279 \mathrm{~m}^{2} . \mathrm{Bu}-$ dynek posiada grawitacyjny systemem wentylacji i jest ogrzewany z miejskiej sieci ciepłowniczej. Na każdym piętrze budynku znajdują się cztery narożne mieszkania, korytarze oraz szyb windowy w centralnej jego części oraz klatka schodowa przy ścianie północnej. Procentowy udział przeszklenia na poszczególnych elewacjach wynosi odpowiednio $\mathrm{N}-8 \%$; S - 40 \%; E-26\%.; W-26\%.

W roku 2004 w budynku została wymieniona stolarka, natomiast w 2006 została wykonana termomodernizacja ścian zewnętrznych budynku. Ściany zewnętrzne wykonane z płyt prefabrykowanych betonowych w systemie W70 o współczynniku $\mathrm{U}=0,20\left[\mathrm{~W} / \mathrm{m}^{2} \mathrm{~K}\right]$ (po dociepleniu $15 \mathrm{~cm}$ warstwą styropianu), w budynku występują okna dwuszybowe o $\mathrm{U}=1,5\left[\mathrm{~W} / \mathrm{m}^{2} \mathrm{~K}\right]$. 
a)

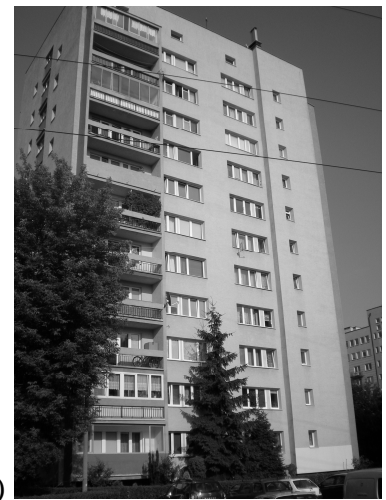

b)

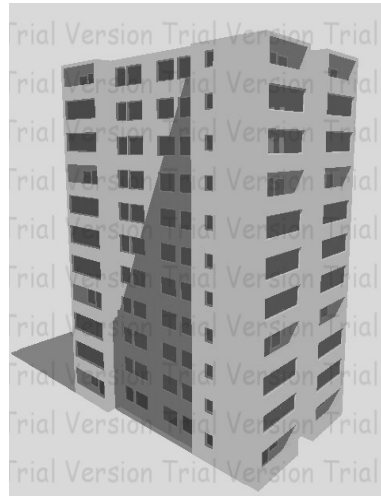

Rys. 1. Analizowany budynek: a) widok budynku od strony zachodniej, b)wizualizacja budynku w programie Design Builder

Fig. 1 Analyzed building: a) view from the west side of the building, b) the visualization of the building in the Design Builder

\section{Założenia do symulacji}

Głównym celem prowadzonych analiz było określenie rozkładu temperatury i wartości wskaźnika PMV dla poszczególnych pomieszczeń mieszkania z przeszkleniami na południe i zachód (Rys. 2), zlokalizowanego na różnych piętrach w okresie letnim. Analizy mikroklimatu całego lokalu jako jednej strefy temperaturowej były przeprowadzane i wykazały, że warunki komfortu cieplnego są znacznie przekroczone. Dlatego przeprowadzono analizę pozwalającą na określenie warunków mikroklimatu $\mathrm{w}$ poszczególnych pomieszczeniach. Mieszkanie to składa się z trzech pokoi o powierzchniach: pok. nr 1 pow. $8,35 \mathrm{~m}^{2}$, pok. nr 2 pow. $7,5 \mathrm{~m}^{2} \mathrm{z}$ oknami skierowanymi na południe i pok. $\mathrm{nr} 3$ pow. $15,65 \mathrm{~m}^{2}$ oraz kuchni o pow. $5,90 \mathrm{~m}^{2}$, łazienki o pow. $4,15 \mathrm{~m}^{2} \mathrm{z}$ oknami skierowanymi na zachód i przedpokoju o pow. $10,25 \mathrm{~m}^{2}$.

Tablica. 1. Powierzchnie analizowanych pomieszczeń oraz powierzchnie przeszkleń

Table. 1 Areas of analyzed rooms and glazing

\begin{tabular}{|c|c|c|c|c|c|}
\hline Pomieszczenie & Usytuowanie & $\begin{array}{c}\text { Powierzchnia } \\
{\left[\mathbf{m}^{\mathbf{2}}\right]}\end{array}$ & $\begin{array}{c}\text { Powierzchnia } \\
\text { przeszklenia } \\
{\left[\mathbf{m}^{\mathbf{2}}\right]}\end{array}$ & $\begin{array}{c}\text { Powierzchnia } \\
\text { ściany zewn. } \\
{\left[\mathbf{m}^{\mathbf{2}}\right]}\end{array}$ & $\begin{array}{c}\text { Udział prze- } \\
\text { szklenia } \\
{[\%]}\end{array}$ \\
\hline Pokój nr 1 & S-E & 8,35 & 3,75 & 7,20 & 52 \\
\hline Pokój nr 3 & E & 15,65 & 2,80 & 8,35 & 33 \\
\hline Kuchnia & E & 5,90 & 1,80 & 4,20 & 43 \\
\hline Lazienka & E & 4,15 & 0,80 & 5,00 & 16 \\
\hline
\end{tabular}




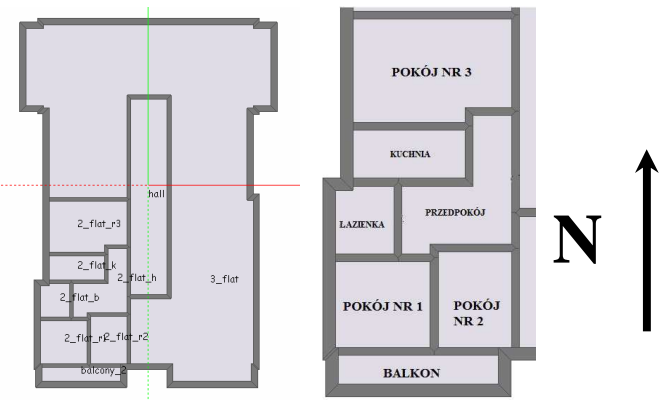

Rys. 2. a) Typowy układ stref temperaturowych na piętrze budynku, b) Rozkład pomieszczeń w mieszkaniu

Fig. 2 a) Typical zones' visulation at every building level, b) Arrangement of rooms in the flat

Analizy symulacyjne zostały przeprowadzone w trzech wariantach:

Wariant 1 - budynek ocieplony w aktualnych warunkach użytkowych;

Wariant 2 - budynek ocieplony z zastosowanymi zacienieniami wewnętrznymi; Wariant 3 - budynek rzeczywisty z zastosowanymi zacienieniami zewnętrznymi oraz wewnętrznymi.

Następnym krokiem było porównanie wyników symulacji dla mieszkania usytuowanego na południowy zachód zlokalizowanego na trzech wybranych poziomach: parter, szóste i dziesiąte piętro. Analizowano okres pomiędzy 15 maja i 15 września, gdyż w tym okresie w Polsce występuje największe ryzyko przegrzewania pomieszczeń.

Ponadto do symulacji przyjęto dodatkowe założenia:

1. Lokal jest ogrzewany od października do marca przez 7 dni w tygodniu, 24 godziny na dobę, przy średniej temperaturze w mieszkaniu $22^{\circ} \mathrm{C}$;

2. Gęstość zaludnienia pomieszczeń stanowi 0,08 osoby na $\mathrm{m}^{2}$, co odpowiada średnio trzem osobom znajdującym się w mieszkaniu;

3. Sposób użytkowania mieszkania to 3 osoby w mieszkaniu pomiędzy 16:00 a 7:00 rano w dni robocze oraz pomiędzy 18:00 i 9:00 rano w okresie weekendu; w pozostałym czasie liczbę użytkowników zredukowano o połowę $(50 \%)$

4. Aktywność fizyczną użytkowników oraz izolacyjność odzieży przyjęto na podstawie normy [1] - aktywność fizyczna $=1,2$ met; izolacyjność odzieży $\mathrm{w}$ okresie zimowym $=1,0$ clo; $\mathrm{w}$ okresie letnim $=0,5$ clo;

5. Wymagania wentylacyjne przyjęto zgodnie z normą PN-83/B-03430 [2], wg której założono wymianę powietrza na poziomie $70 \mathrm{~m}^{3} /$ godzinę w kuchni oraz $50 \mathrm{~m}^{3} /$ godzinę w lazience, bez uwzględnienia odwrotnego ciągu powietrza;

6. Zacienienia wewnętrzne w postaci ruchomych żaluzji poziomych o współczynniku odbicia promieniowania słonecznego 50\%, zacienienia zewnętrzne w postaci stałych żaluzji zewnętrznych. 


\section{Wyniki przeprowadzonych symulacji}

Przeprowadzone symulacje dla budynku ocieplonego, których wyniki przedstawiono poniżej, pokazują, że w okresie pomiędzy 15 maja, a 15 września, występują przekroczenia średnich temperatur powietrza wewnętrznego. Zarejestrowano temperaturę powyżej $32^{\circ} \mathrm{C}$ oraz wskaźnik PMV większy od 2 . Takie warunki mikroklimatu znacznie przekraczają zalecane maksymalne wartości temperatury $\left(25^{\circ} \mathrm{C}\right)$ oraz zalecany przedział wartości wskaźnika PMV $(-0,5<$ PMV $<+0,5)$.

Wykresy 3a, 3b, 3c oraz 3d przedstawiają rozkład ilości godzin przegrzania dla pokoju nr 1 i nr 3 oraz kuchni i łazienki mieszkania zlokalizowanego na parterze, szóstym i dziesiątym piętrze w analizowanych miesiącach.
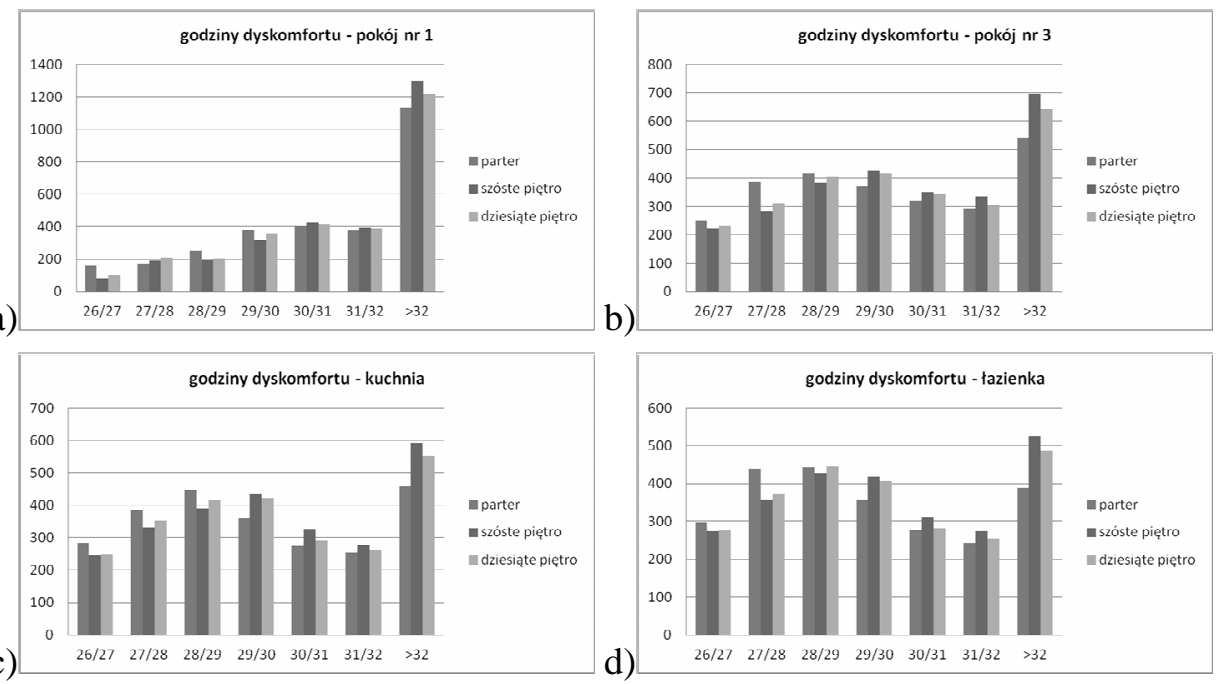

Rys. 3. Liczba godzin przegrzania dla poszczególnych pomieszczeń południowo - zachodniego mieszkania na różnych piętrach

Fig. 3 Number of discomfort hours for different rooms of south-west dwelling at different levels

We wszystkich pomieszczeniach niezależnie od piętra występuje problem przegrzewania. Zwracając uwagę na orientację mieszkania i skierowanie okien, a także udział przeszklenia, najniekorzystniejsze warunki pod względem komfortu cieplnego występują w pokoju nr 1, który jest o połowę mniejszy od pokoju $\mathrm{nr} 3$, a powierzchnia przeszklenia jest większa o $25 \%$ i usytuowana jest od południa (Tabela 1). Liczba godzin o temperaturze powyżej $32^{\circ} \mathrm{C} \mathrm{w}$ okresie letnim przekracza $1200 \mathrm{i}$ jest to $50 \%$ więcej niż w pokoju $\mathrm{nr} 3$ usytuowanym od zachodu. W pozostałych pomieszczeniach liczba godzin dyskomfortu jest podobna, gdyż są to pomieszczenia usytuowane od zachodu. 
Wartości wskaźników PMV przekraczają wartość 2 w przypadku wszystkich pokoi, a w lipcu wartości te są nawet większe od 4 . Rysunki 4a oraz $4 \mathrm{~b}$ przedstawiają wartości PMV w analizowanym okresie czasu pomiędzy 15 maja a 15 września dla pokoju nr 1 i pokoju nr 3 na poszczególnych analizowanych piętrach.

a)
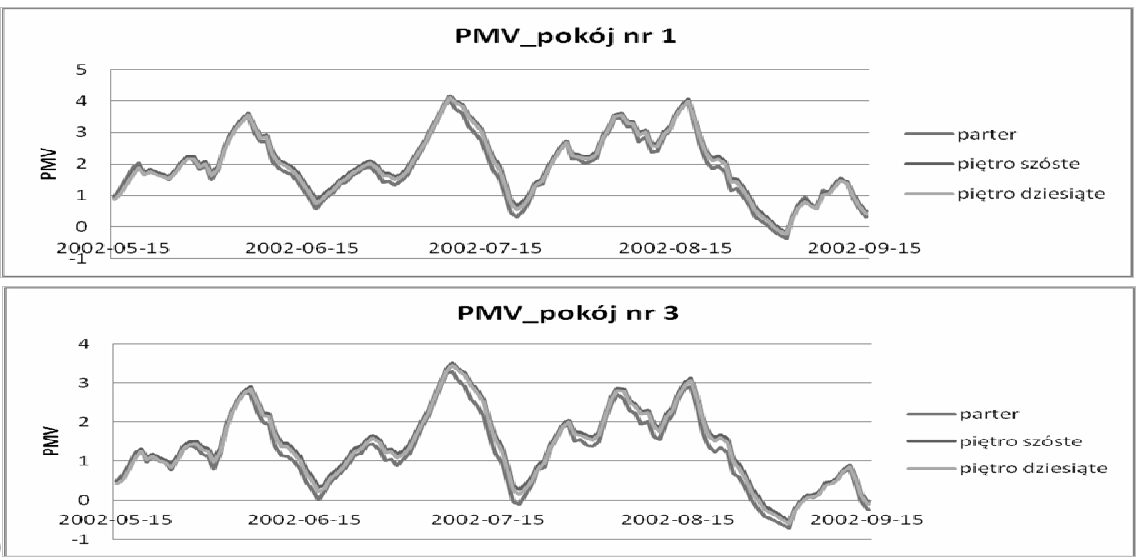

Rys. 4. a) Wskaźnik PMV dla pokoju nr 1 na różnych piętrach b) Wskaźnik PMV dla pokoju nr 3 na różnych piętrach

Fig. 4 a) PMV index for room number 1 at different levels, b) PMV index for room number 3 at different levels

Kolejnym etapem analiz było zastosowanie zacienień wewnętrznych w postaci poziomych ruchomych żaluzji wewnętrznych. Tego typu osłony korzystnie wpływają na warunki mikroklimatu w analizowanych pomieszczeniach. Rys. $5 \mathrm{a}, 5 \mathrm{~b}, 5 \mathrm{c}$ i $5 \mathrm{~d}$ przedstawia wyniki symulacji dla pomieszczeń w mieszkaniu w poszczególnych miesiącach, na różnych piętrach po zastosowaniu zacienień wewnętrznych. Porównując $\mathrm{z}$ analogicznymi wykresami dla budynku bez zacienień wewnętrznych (Rys. 3a, 3b, 3c i 3d) obserwujemy nieznaczną poprawę warunków mikroklimatu wewnątrz analizowanych pomieszczeń.

Liczba godzin przegrzania $\mathrm{w}$ analizowanym okresie czasu w pokoju $\mathrm{nr} 1$ wynosiła 2915 i zmniejszyła się do wartości 2892, a dla porównania w pokoju $\mathrm{nr} 3 \mathrm{z}$ wartości 2700 do 2488 . Natomiast liczba godzin o temperaturze powyżej $32^{\circ} \mathrm{C}$ w okresie letnim przekraczała 1096 i jest to $50 \%$ więcej niż w pokoju $\mathrm{nr} 3$ usytuowanym od zachodu, gdzie liczba godzin wynosiła 507. W pozostałych pomieszczeniach liczba godzin dyskomfortu jest podobna. 


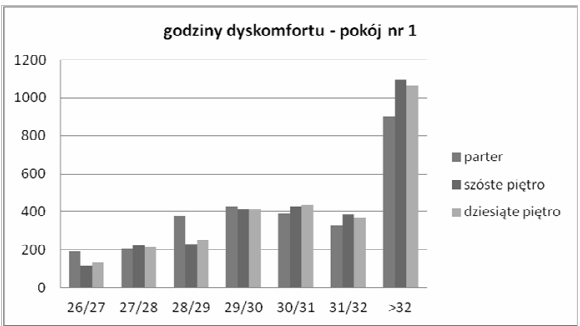

a)

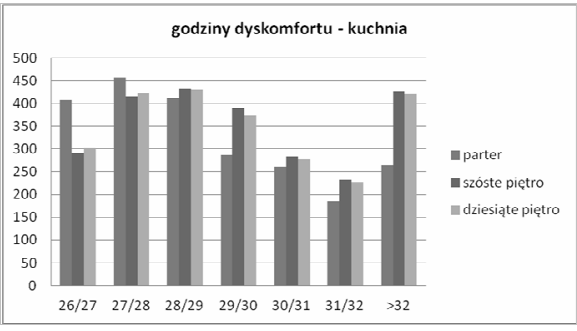

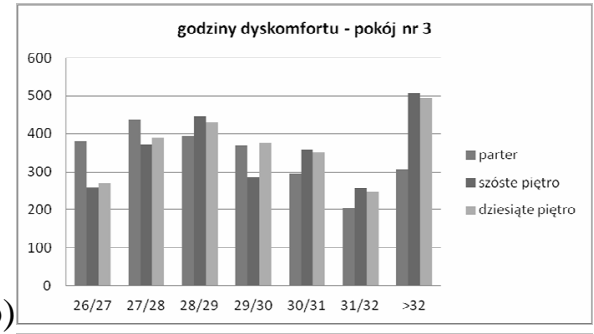

b)

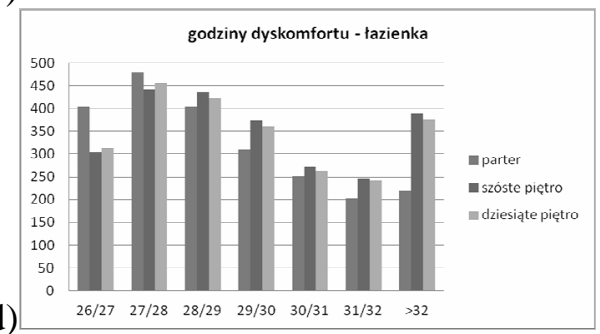

Rys. 5. Liczba godzin przegrzania dla poszczególnych pomieszczeń południowo - zachodniego mieszkania na różnych piętrach, z uwzględnieniem zacienień wewnętrznych

Fig. 5 Number of discomfort hours for different rooms of south-west dwelling at different levels with internal shadings

Wartości wskaźników PMV nadal przekraczają wartość 2 jednak maksymalna wartość uległa nieznacznemu obniżeniu z wartości 4,16 do wartości 3,9. Wyniki przedstawiają rys. 6 a oraz $6 b$.

a)

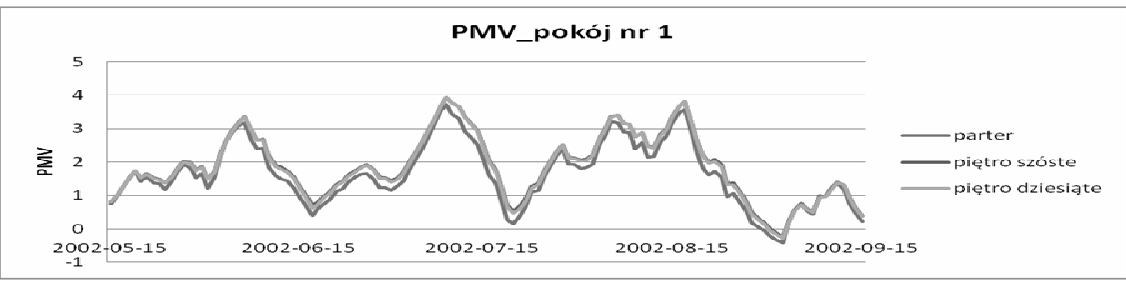

b)

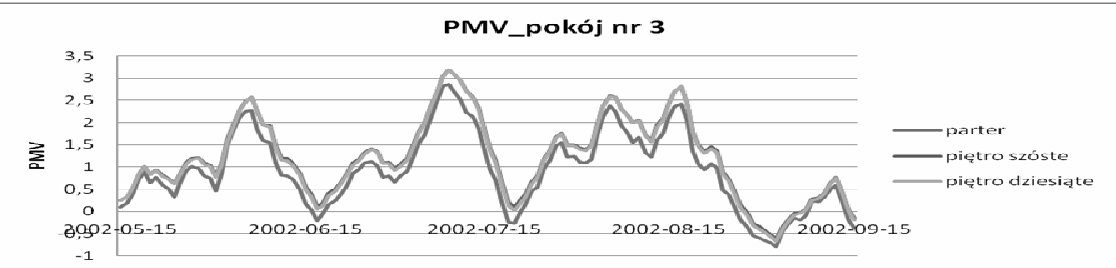

Rys. 6. a) Wskaźnik PMV dla pokoju nr 1 na różnych piętrach z uwzględnieniem zacienień wewnętrznych, b) Wskaźnik PMV dla pokoju nr 3 na różnych piętrach z uwzględnieniem zacienień wewnętrznych

Fig. 6 a) PMV index for room number 1 at different levels including internal shadings, b) PMV index for room number 3 at different levels including internal shadings 
Ostatnim etapem symulacji było dodanie do analizowanego budynku z zacienieniami wewnętrznymi osłon zewnętrznych w postaci stałych żaluzji poziomych umieszczonych na odległości 1,0 m od górnej krawędzi okna. Ten etap modernizacji budynku znacznie polepszył warunki mikroklimatu w analizowanych pomieszczeniach.

Rysunek 7a, 7b, 7c i 7d przedstawia wyniki kolejnego etapu symulacji dla tych samych pomieszczeń w poszczególnych miesiącach, na różnych piętrach po zastosowaniu zacienień wewnętrznych oraz zacienień zewnętrznych. Ponownie porównano wyniki $\mathrm{z}$ analogicznymi wykresami dla budynku bez zacienień (Rys 3a, 3b 3c oraz 3d). Nastąpiła znaczna poprawa warunków mikroklimatu wewnątrz wszystkich analizowanych pomieszczeń.
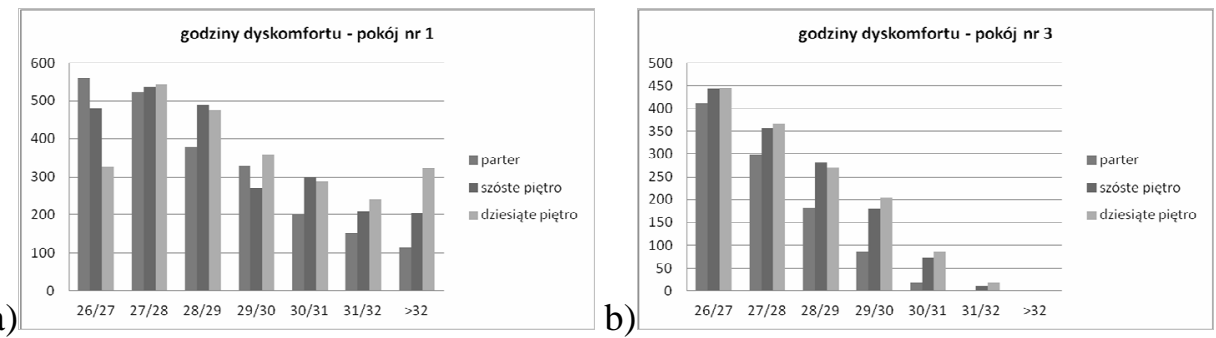

a)

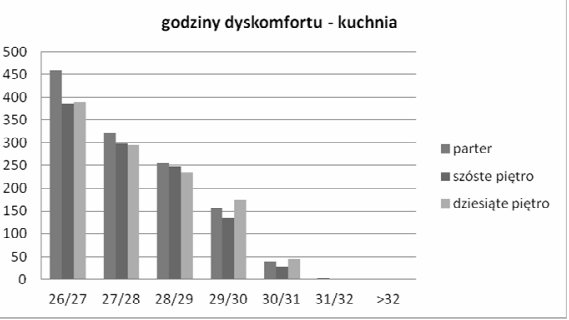

b)

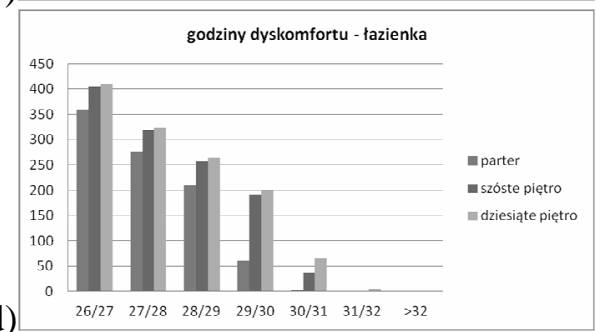

Rys. 7. Liczba godzin przegrzania dla poszczególnych pomieszczeń południowo - zachodniego mieszkania na różnych piętrach, z uwzględnieniem zacienień wewnętrznych oraz zewnętrznych

Fig. 7 Number of discomfort hours for different rooms of south-west dwelling at different levels with internal and external shadings

Liczba godzin przegrzania $\mathrm{w}$ analizowanym okresie czasu w pokoju $\mathrm{nr} 1$ została zredukowana $\mathrm{z}$ wartości $2915 \mathrm{w}$ stanie rzeczywistym do 2488 czyli o $15 \%$, a w pokoju $\mathrm{nr} 3 \mathrm{z}$ wartości 2700 do 1346 czyli o 50\%. Liczba godzin o temperaturze powyżej $32^{\circ} \mathrm{C}$ została znacznie zredukowana w pokoju $\mathrm{nr} 1$ do wartości 324 czyli o $75 \%$ w stosunku do budynku bez zacienień. Natomiast w pomieszczeniach usytuowanych od zachodu temperatury powyżej $32^{\circ} \mathrm{C}$ zostały całkowicie zredukowane.

Również wartości wskaźników PMV uległy ponownemu znacznemu obniżeniu z wartości 4,16 do 2,6 dla pokoju nr 1 i z wartości 3,5 do 1,7 dla pokoju $\mathrm{nr} 3$, co przedstawia rys. $8 \mathrm{a}$ oraz $8 \mathrm{~b}$. 
a)

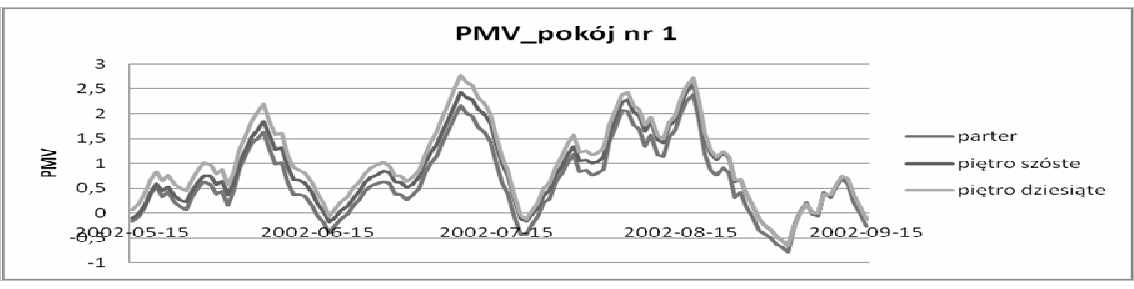

$$
\text { b) }
$$

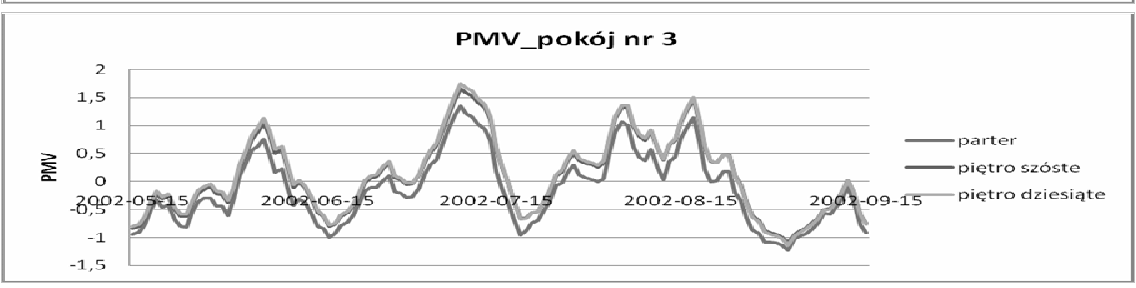

Rys. 8. a) Wskaźnik PMV dla pokoju nr 1 na różnych piętrach z uwzględnieniem zacienień wewnętrznych i zewnętrznych, b) Wskaźnik PMV dla pokoju nr 3 na różnych piętrach $\mathrm{z}$ uwzględnieniem zacienień wewnętrznych i zewnętrznych

Fig. 8 a) PMV index for room number 1 at different levels including internal and external shadings, b) PMV index for room number 3 at different levels including internal and external shadings

\section{Wnioski}

Mikroklimat wszystkich analizowanych pomieszczeń budynku wielorodzinnego jest niekorzystny, a parametry komfortu cieplnego przekraczają wartości dopuszczalne. Należałoby zatem, podczas projektowania docieplenia, uwzględnić zastosowanie zewnętrznych oraz wewnętrznych osłon zacieniających, które znacznie zminimalizowałyby efekt przegrzania. Zabiegi takie niestety są drogie i analizie ekonomicznej inwestycji termo modernizacyjnej zostanie zapewne odrzucona z uwagi na brak możliwości oceny „wartości” komfortu cieplnego mieszkańców.

\section{Artykut przygotowano w ramach prac L-1/116/DS/2013}

\section{Literatura}

[1] PN-EN ISO 7730. Ergonomics of the thermal environment. Analytical determination and interpretation of thermal comfort using calculation of the PMV and PPD indices and local thermal comfort criteria.

[2] PN-83/B-03430. Wentylacja w budynkach mieszkalnych zamieszkania zbiorowego i użyteczności publicznej. Wymagania.

[3] Nowak K.: Modernizacja budynków a komfort cieplny pomieszczeń. Energia i Budynek, ISSN 1897-5879, s.29-33 2011.

[4] Dębowski J.: Cała prawda o budynkach wielkopłytowych Przegląd budowlany 9/2012. 
[5] Nowak K., Nowak-Dzieszko K., Rojewska-Warchał M.: Thermal comfort of the rooms in the designing of commercial buildings. Research and Applications in Structural Engineering, Mechanics and Computation. SMEC Cape Town 2013 s.651-652.

\title{
ANALYSIS OF MICROCLIMATE CONDITIONS IN THE DWELLING OF LARGE PANEL W70 BUILDING
}

\begin{abstract}
S u m m a r y
It is estimated that in Poland, between 1960-1990, more than 4 million buildings were built in different prefabrication systems. What is more, it is estimated that at present more than 10 million Poles live in those large panel buildings, however those data are not very precise and confirmed. Nevertheless it makes the problems connected with proper usage, thermal insulation and first of all with reducing of heating energy demand of prefabricated large panel buildings, to be very important and common. The dominant criterion in the process of thermal modernization is to improve the energy performance of those buildings, in which the most common are insulation of building envelope combined with replacement of windows. However in the analyzing and designing process of thermal modernization no one takes into consideration aspects connected with thermal comfort and overheating problems in those buildings, which appear to be very important from the occupants' point of view. The paper presents the results of the annual computational simulations of microclimate conditions in the dwelling of W70 prefabricated panel building, made in W70 system, located at different levels of multi-family block of flats. Most of the dwellings in the multi-family large panel buildings has the usage area of about $50-60 \mathrm{~m}^{2}$. Usually at this relatively small area there are three rooms, kitchen and bathroom which makes the rooms to be very small. Average number of occupants in a single flat is three. The facts mentioned above unfavorably affects the thermal comfort of the separate rooms what was confirmed by the simulations.
\end{abstract}

Keywords: large panel building, W70 system, thermal comfort, prefabricated panel buildings

Przestano do redakcji: $22.06 .2015 \mathrm{r}$.

Przyjęto do druku: 30.10.2015 r.

DOI:10.7862/rb.2015.114 